\title{
Carl Ludwig and Emil du Bois-Reymond: A Study in Contrasts
}

\author{
By Paul F. Cranefield
}

In thanking you for the invitation to appear before you I must also apologize for speaking on a subject slightly different from the one that was originally announced on the program. I was originally invited to address you on the subject of "Carl Ludwig, Emil du Bois-Reymond and Swiss Physiology". I suggested alternatives: "Carl Ludwig: Physiology As Measurement" or perhaps "Carl Ludwig and Swiss Physiology". But the recent Zürich thesis of Dr. Zupan ${ }^{1}$, examines Ludwig's Zürich years and Ludwig's later influence on Swiss Physiology in great detail and presents much valuable new information, to which I could add nothing. As to "Carl Ludwig: Physiology as Measurement", that is, after all, the main theme of Schröer's excellent biography of Ludwig ${ }^{2}$. And so I returned, indeed found myself drawn back, to my original subject: "Carl Ludwig and Emil Bois-Reymond", but with an added subtitle: "A Study in Contrasts."

I will begin with the briefest of sketches of these men, to orient those who are not historians of physiology. Ludwig and du Bois-Reymond were among the most famous and influential medical scientists of the 19th century ${ }^{3}$. Although Ludwig's research was far ranging, much of it dealt in one way or another with the cardiovascular system. Du Bois-Reymond's interests were narrowly focused on a single subject, a subject once called Animal Electricity and now called electrophysiology.

Each of these "representative men" had a connection to Switzerland; that is why I was invited to talk about them. Emil du Bois-Reymond was born in Berlin in November 7, 1818. His mother was French; she was the daughter of the minister of the French community of Berlin. One of her grandfathers was the artist Daniel Chodowiecki, who was born in Danzig. He was Polish by name and by ancestry, but he was German by residence, even to the point of becoming the director of the Berlin Academy of Art. Du BoisReymond's family spoke French and they were part of the French community of Berlin. Du Bois-Reymond attended the French speaking "gymnasium" in Berlin. He attended university in Berlin, he spent his entire academic career in Berlin, he was twice Rector of the University of Berlin, and he became one of the Permanent Secretaries of the Prussian Academy of 
Sciences. He was born in Berlin, he lived in Berlin all of his life, and he died there, on December 26, 1896. He became a fierce German nationalist, even though, as Diepgen puts it, French and Slavic blood flowed in his veins ${ }^{4}$. He was a life-long resident of Berlin, literally from birth to death. But, as we all know, he was Swiss. His father was born in Neuchatel, and if du BoisReymond does not impress the average modern reader as having been Swiss, that is nevertheless how Carl Ludwig thought of him. Soon after taking up his chair in Zürich, Ludwig wrote to du Bois-Reymond and spoke of the local beauty of nature, "which you, as a Swiss, know and love" 5.

Du Bois-Reymond's background may have had something to do with his rather complex personality. He was a gifted artist and was proud of his descent from Chodowiecki. Although he was Swiss, he was brought up speaking French in Berlin; when France and Germany were at war he expressed German nationalistic views of an obnoxious kind; and, early in his career, he seriously considered settling permanently in London. In Lewin's term, he was "marginal" figure, at the border of many cultures.

Not so Ludwig! Ludwig was purely German. He was born on December 29,1816 , at the end of the famous "year without a summer", of which I will speak again. Although he was born long before the unification of Germany, he was quintessentially German, even down to his dueling scars. His father's father, Georg Ludwig, was a merchant in Kassel, his mother's father, Johann Nagel, was a forester. His father, Friedrich Ludwig, began life as a professional soldier in the service of the Prince of Hesse, and, after the Napoleonic Wars, became a Rentmeister (steward) in Hanau. Ludwig was born in Witzenhausen and spent his first nine years there; then the family moved to Hanau, where he graduated from the humanistic gymnasium. An apparently solid, conventional and respectable background, no artists, no ministers, no Slavic or French blood in his veins! But there must have been some intellectual streak or other in the family, since three of the Ludwig brothers became scholars - one a physiologist; one a geologist; and the third, an art historian ${ }^{6}$.

Ludwig studied medicine at Marburg, where he worked with Bunsen, an important event that $I$ will allude to again, and remained at Marburg until he was 33. At Marburg he was connected both with the anatomical institute and with physiology. Diepgen ${ }^{7}$ tells us that Ludwig was not happy in Marburg, but he at least managed to become famous there, inventing both his filtration theory of urine formation and the kymograph. He was released from Marburg by the call to Zürich, where he held the chair, as we all know, 
from 1849 to 1855 , when he left for Vienna where he stayed (at the Josephinum) until 1865 . Thus the purely German Ludwig spent 16 years of his career in Zürich and in Vienna.

Already almost 50 in 1865 , he finally arrived at his permanent address, Leipzig. There he built a new institute, which was not finished until he was 53. He remained highly productive both of discoveries and of students until to his death 26 years later, on April 23, 1895. Du Bois-Reymond burned out as a scientist in his 50 's - some of the most productive years of Ludwig's life corresponded to the least productive of du Bois-Reymond's.

Ludwig was born in 1816; du Bois-Reymond died in 1896. We like to think that we live in a time of unprecedented scientific change and revolution and that the sciences of molecular biology and immunology are about to deluge us with benefits. That may be so, but we should, I think, be a little cautious in comparing those 80 years, 1816-1986, to the 80 years, not yet over, to be sure, 1916-1996.

Let me start with a single example, one that encapsulates the rest: Ludwig was already four years old when Oersted discovered that an electric current generates a magnetic field; by the time du Bois-Reymond died Roentgen had discovered the X-ray, Hertz had detected electromagnetic signals over a distance of 60 meters and Marconi had detected those signals at a distance of over a mile. I will mention a few examples of the conveniences and inconveniences of modern life that we all take for granted today: aspirin and machine guns, the train and the automobile, the phonograph and the photograph, the ball point pen and the typewriter, the widespread availability of electric power, the telegraph and the telephone, and the elevator. None of those things existed when Carl Ludwig was born; all of them existed before he died. His voice could have been preserved for us by the phonograph, his image was preserved for us by photography, but could not have been before he was 21 . He read and wrote, presumably, by candle light or by oil lamps, initially fueled by whale oil and later by coal oil, and then by gas mantle, and, finally by electric light. He traveled, or could have done, by stage coach, by steam train, by electric train or tram, and even by automobile. Those 80 years also saw the discovery of the periodic table; the enunciation of the law of the Conservation of Energy; the development of modern thermodynamics; the discovery of spectroscopy; the development of modern physical chemistry; and the development of modern organic chemistry. In du Bois-Reymond's field of electricity, those years saw the publications of Oersted, Ampere, Ohm, Faraday, Helmholtz, Maxwell, 
Hertz, Roentgen, and even Marconi, who began what was to become radio and television.

In many ways, 1896 is just around the corner whereas, in some ways, life in 1816 was closer to life in the Roman empire, at least if we overlook such details as gunpowder, firearms and the stationary steam engine! You may think that I exaggerate in speaking as if all this occurred within living memory. Well, of course, it did not, at least not quite! But you would have said the same thing a year ago. And a year ago you would have been wrong, because Hermann von Siemens was still alive a year ago ${ }^{8}$. Both of Hermann von Siemens' grandfathers were born before Oersted discovered that the flow of an electric current generates a magnetic field. In 1847, one of his grandfathers, Werner von Siemens, founded Siemens \& Halske; in the same year, his other grandfather, Hermann von Helmholtz, announced the Law of the Conversation of Energy. Born in 1885, Hermann von Siemens knew Helmholtz, knew Werner von Siemens, and, without the slightest doubt, knew Helmholtz's life-long friend, Emil du Bois-Reymond. Thus the latter part of the era of which I speak is not beyond the reach of a single life time.

What about Carl Ludwig? I have already said that he began his career at Marburg. One cannot discuss the beginning of that career without mentioning the remarkable role played by Bunsen in relation to 19th century physiology ${ }^{9}$. It was in Bunsen's laboratory in Marburg that Ludwig learned Bunsen's new techniques of gas analysis, techniques which Bunsen developed from 1838 to 1845, while Ludwig was in Marburg. The founder of modern Russian physiology, Sechenov, whom we think of as a neurophysiologist but who was also interested in blood gases all of his life, studied first with Ludwig in Vienna and later with Bunsen. The great physical chemist, Lothar Meyer, began his career in the medical school of Zürich, where he worked with Ludwig on blood gases. Ludwig sent Meyer to Bunsen, who turned him into a physical chemist. (That particular transformation was one of the more important results of Ludwig's stay in Zürich.)

The time that Ludwig spent with Bunsen was crucial to his future career, devoted as it was to the application of physical and physical-chemical techniques to physiological problems, such as the filtration theory of urine formation. That theory, plus the introduction of the kymograph, and the discovery of secretory nerves, might have made anyone famous, but they make up a small part of Ludwig's accomplishments, many of which, as we all know, relate to the physiology of the cardivascular system ${ }^{10}$. Measurements 
of blood flow (with his stromuhr), of blood pressure (with the mercury manometer and his kymograph), measurements of the blood gases (with his own modifications of Bunsen's techniques), the discovery of ventricular fibrillation (Ludwig and Hoffa), of the all-or-nothing law of the heart (Bowditch), the discovery of the medullary vasomotor center, the discovery of the depressor nerve (Cyon and Ludwig), the discovery of the positive inotropic effect of sympathetic nerve stimulation (Pavlov): the list is not endless, but it is very long and very impressive.

My old Professor, Walter Meek, had two heroes, Carl Ludwig and Claude Bernard. When he spoke of Ludwig he always reminded us that "Die Methode ist alles": the method is everything. The saying was Ludwig's, but it is a bit of a simplification. Ludwig, master inventor of specific methods, was much more than that. I believe that by "method" Ludwig meant the entire strategy of the experiment. It seems to me that, above all else, what lay at the heart of Ludwig's "method" was his ability to identify solvable problems. Every student of Ludwig's career has noted his gift for matching the problem to the student, and his gift for inventing specific techniques for obtaining specific kinds of quantitative information. But it is misleading to think of Ludwig only in terms of his ability to invent or apply particular physical or chemical techniques to the obtaining of particular kinds of quantitative measurements. He was also a master histologist-he wrote the chapter on the kidney for Stricker's great Handbook; he was a gifted physiological surgeon; and he was the greatest single teacher of physiological research in the history of the field.

But his greatest gift lay in his ability to find one important problem after another that could be studied and solved by using methods already available, or by using methods the modification of which was within practical reach. So, although "The method is everything", Ludwig's methods were secondary to his "method". That "method" was the art of the physiological experiment: the ability to identify a solvable problem, to devise the techniques to study it, to execute the experiment and to interpret the results. In that sense, the method is indeed everything.

His greatest pupil and most direct successor in the application of diverse techniques, including masterful surgical techniques, astute observation and clever experimental design, was Pavlov. Pavlov's studies of the gastrointestinal system, published only two years after Ludwig's death, seem to me in some ways to be the crowning achievement and high-water mark of Ludwig's kind of physiology. 
Du Bois-Reymond is much harder to pin down than Ludwig. More various, more complex, and in many ways less successful as a scientist, in his day he was probably more famous in the world at large. To begin, I will comment on him as a scientist. As he said in 1876, in the preface to his collected papers ${ }^{11}$ : "I was just 22 years old when Johannes Müller put to me the problem of the source of Nobili's frog current, and I am still concerned, 43 years later, with that problem." He never solved that problem nor could he have solved it, because the physical chemistry of the period, adequate to the problems studied by Ludwig, was not adequate to explain the origin of either the resting potential or the action potential. It was not for want of trying nor for lack of hard work: His early book, Untersuchungen über Thierische Elektricität, is 1,800 pages long ${ }^{12}$. His articles, collected and reissued in 1876, contain another 1,100 pages ${ }^{11}$, and his popular lectures occupy another 1,600 pages $^{13}$. And yet, in a way, he failed. On the one hand, he was a giant, the creator of a field, a developer of essential techniques (such as very sensitive galvanometers and the nonpolarizable electrode), he was the discoverer of the action potential, and the first to observe electrotonic changes. But Arrhenius did not introduce the concept of the ion until the 1880 's and Nernst's electrochemistry did not appear until the 1890 's. The cornerstones of modern electrophysiology are the core-conductor model and the ionic basis of the resting potential and the action potential, and both eluded du Bois-Reymond, although they were indeed developed by his students, Ludimar Hermann and Julius Bernstein. He had important students, but they were few in number compared with those of Ludwig. He also gave a powerful impetus to the study of the electric eel and of electric fish, but there again his work was surpassed by his students, especially Fritsch. Thus many of the fundamental contributions in the field were not made by du BoisReymond, but by his students. He was a fore-runner, a great fore-runner, but, nevertheless, a fore-runner. And he knew that and he felt it keenly. He had to abandon his plan to write a general theoretical conclusion to his Untersuchungen. He published a section of that book in 1860 and a final fragment, written long before, in 1884, accompanied by a famous Nachwort, in which he said, as he had already implied in 1876, that the Untersuchungen remains a stump, a torso, a Monstrum per defectum, lacking the overall theoretical synthesis promised in the preface written 36 years before ${ }^{14}$.

And that brings us to the heart of my problem with du Bois-Reymond. What kind of scientist, in 1848, would promise to produce a general theory, 
relating the electrical activity of nerves and muscles to the remaining phenomena of their living activity? Ludwig would never have made such a promise and one would hesitate to make such a promise today!

But it was not out of character for du Bois-Reymond to make that promise. He was a scientist, to be sure, but he was much else besides. He was widely read in history, literature and philosophy, and often quoted from books on those subjects, in English, French, German and Latin. He began life thinking that he would study theology and he remained, for all of his life, interested in sweeping philosophical questions. He was, in 1848, the crusader for the 1847 biophysical group's antivitalist position ${ }^{15}$. Ludwig, Brücke and Helmholtz may have agreed with him, but he was the zealous preacher and harsh polemicist. His famous and often sarcastic essay on the Lebenskraft was part of the preface to his 1848 book, complete with its famous assertion that, in principle, analytical mechanics can reach even to the problem of "Freedom of the Will". ${ }^{16}$ And he often argued in harshly polemical terms, so harsh that he regularly apologized for that in later years. His earliest victim was another Swiss physiologist, Valentin, whom he labeled the "Bernese iatromathematician". When he published his essay on the Lebenskraft in his Reden he apologized for his attacks on Valentin, saying that he could not, unfortunately, remove those attacks from his essay, because they were so woven into its fabric. In the preface to his Gesammelte Abhandlungen he apologizes for the polemical quality of some of the articles he reprinted. He seems so often to have known the answer on a priori grounds.

I will now make what may seem to be a curious digression, and remind you that 1818, the year of du Bois-Reymond's birth, also saw the publication of a famous novel about a "scientist" who is today far more famous than Ludwig or du Bois-Reymond, and who, perhaps because he was the creature of the imagination of a gifted novelist, may be the most famous experimental scientist of all time. His "biographer" tells us that he too was Swiss, born in Geneva-his name was Dr. Victor Frankenstein ${ }^{17}$. I mentioned earlier that Carl Ludwig was born in 1816, the year without a summer. There was no summer that year because the eruption of Mount Tambora in 1815 had filled the sky with volcanic ash. Because there was no summer in 1816, Byron, Shelley and Mary Shelley, visiting the Villa Diodati, had to spend much of their time indoors, sitting near the fireplace. They spent that time inventing ghost stories. It was Mary Shelley who created the "biography" of Victor Frankenstein. In view of Dr. Frankenstein's bad reputation I should add that although he was conceived in the Villa Diodati and was said 
to have been born in Geneva, he was also said to have been educated in Ingolstadt, and to have conducted his famous experiment there.

They were, all of them, Shelley, Byron, Mary Shelley and Victor Frankenstein, obsessed with the recent findings of Galvani, Volta and Aldini, and by the notion that electricity is the secret essence of life. And I will go further, and suggest that du Bois-Reymond had the same obsession. Du Bois-Reymond, the great opponent of vitalism, had scorned the idea of a Lebenskraft or life force. And yet he had proposed to relate the electrical characteristics of nerve and muscle to their "general vital activity". And he spoke of the impact of Galvani's work of 1791 as being almost equal to the impact of the French Revolution.

If you think this a wholly fanciful idea, permit me to cite a few words by Shakespeare (Henry IV, part 1):

"And now I will unclasp a secret book

"And read you matter deep and dangerous,

...full of peril."

You might well think that Mary Shelley had used those words to introduce her novel Frankenstein. But Mary Shelley prefaced her novel with a few lines written by an earlier visitor to the Villa Diodati, John Milton (Paradise Lost, $\mathrm{X}, 743-5)$ :

"Did I request thee, Maker, from my clay,

To mould me Man? Did I solicit thee

From darkness to promote me?-

We should remember that Mary Shelley's novel had a sub-title : Frankenstein or the Modern Prometheus!

No, Shakespeare's lines, "and now I will unclasp a secret book and read you matter deep and dangerous... full of peril" were chosen by du BoisReymond to preface later reprintings of his 1848 essay on the life force or Lebenskraft ${ }^{18}$. I will dare to say it: In his heart of hearts, du Bois-Reymond, the standard bearer of the mechanistic and anti-vitalist movement, really believed that there is a secret of life, a vital force, and that that vital force is animal electricity. Du Bois-Reymond was a visionary and had a life-long tendency to adopt sweeping philosophical positions. I suggest that he devoted his life to the study of animal electricity because he thought that 
animal electricity contained and embodied the secret of the life force. Diepgen wrote an admirable preface to the Ludwig-du-Bois-Reymond correspondence ${ }^{19}$, and in it he said only one thing that I disagree with: "For both of them scientific research is their whole life." True, perhaps, of Ludwig; not of du Bois-Reymond. Ludwig did give his whole life to physiology, and was productive in his 78th year; du Bois-Reymond gave at least half of his life to matters other than physiology and left the field before he was 60 , to become a popularizer, a public figure, a scientific statesman and a philosopher. A brilliant career, but not that of a man for whom scientific research was his whole life.

\section{Epicrisis}

I will close with a few personal impressions of an unhistorical nature. What did these men have in common? As Diepgen said ${ }^{20}$, and as I hope I have shown, "they were thoroughly unlike in descent and in temperament." Ludwig, the practical man, both feet on the ground and both hands on the experiment, a master discoverer, a master inventor of methods, a man with a gift for identifying one important solvable problem after another over a period of 55 years; Ludwig, an undoubted German, who spent 16 of the best years of his life in Zürich and Vienna.

Du Bois-Reymond, visionary, romantic, a priorist, polemicist, founder of modern electrophysiology, whose career consisted of some 40 years dedicated to a single unsolvable problem; an undoubted Swiss who spent his whole life and career in Berlin. Why do we speak of them in one breath? They were, of course, life-long friends, and they certainly shared in the effort to infuse physiology with the methods and thinking of physics and physical chemistry. They also shared, with many of their colleagues, something entirely different. In some quite real sense they were men of our time. After all, many of us could have known or did know pupils of Ludwig. Max von Frey died in 1932, Pavlov died in 1935, Otto Frank died in 1944.

In the mid-1930's, when I was ten or eleven years old, I met a pupil of Ludwig. My grandfather took me to meet his old friend, the great biologist E. A. Birge. I had, of course, never heard of Ludwig at that time and it would have meant nothing to me if I had been told that Birge had studied with Ludwig more than fifty years before, in 1882. Some of you may have visited Professor Ackerknecht in Madison, in the early years of his stay there. Those 
who did that could have met that same pupil of Ludwig, E. A. Birge, who did not die until 1950, aged 98.

And now I will become totally unhistorical, but this is a joint meeting with The Physiological Society and I am, after all, a physiologist. As a physiologist, I am convinced that if a more subtle and skillful Victor Frankenstein could bring Ludwig and du Bois-Reymond back to us, each with the physical and mental energy he had at the age of 40 and with the knowledge he had accumulated by age 70 , those men would, after six months or a year of intensive tutoring and "catching up", feel completely at home in the laboratory and be able to make valuable contributions. That is more than I could say for Aristotle, or for Haller, or perhaps, even for Magendie. And, indeed, it is more than I can say for the average graduate student, who needs more than a year to "catch on" to the work of a laboratory.

Dr. Bynum entitled his lecture: "It is a patient!" Of both Ludwig and du Bois-Reymond, I can say: "He is a colleague!"

\section{Notes}

1 Zupan, Peter: Der Physiologe Carl Ludwig in Zürich. 1849-1855. Zürich: Juris Druck \& Verlag, 1987. [Zürcher Medizingeschichtliche Abhandlungen Nr. 186.]

2 Schröer, Heinz: Carl Ludwig. Begründer der messenden Experimentalphysiologie. 1816-1895. Stuttgart: Wissenschaftliche Verlagsgesellschaft m.b. H., 1967.

3 du Bois-Reymond, Estelle (Hrsg.): Zwei grosse Naturforscher des 19. Jahrhunderts. Ein Briefwechsel zwischen Emil du Bois-Reymond und Carl Ludwig. Vorwort, Anmerkungen und Register von Paul Diepgen. Leipzig: Barth, 1927. English translation: du BoisReymond, Estelle. Two Great Scientists of the Nineteenth Century. Correspondence of Emil du Bois-Reymond and Carl Ludwig. Foreword, notes and indexes by Paul Diepgen. Translated by Sabine Lichtner-Ayèd. Edited, with a foreword, by Paul F. Cranefield. Baltimore: Johns Hopkins University Press, 1982 (page references in subsequent citations are to the English version).

4 See n. 3 supra, p. xiv.

5 See n. 3 supra, p. 57.

6 For biographical information about Ludwig, see n. 2 supra.

7 See $n .3$ supra, p. $x v$.

8 Hermann von Siemens was born on August 9, 1885; he died, at the age of 101, on October $13,1986$.

9 Cranefield, Paul F.: Robert Bunsen, Carl Ludwig and Scientific Physiology. In: F. F. Kao, K. Koizumi and M. Vassalle (eds.): Research in Physiology: a liber memoralis in honor of Prof. Chandler Mc Cuskey Brooks, Bologna: Aula Gaggi, p. 74.3-748.

See n. 2 supra. 
11 du Bois-Reymond, Emil: Gesammelte Abhandlungen zur allgemeinen Muskel- und Nervenphysik. Leipzig: Veit, vol.1, 1875; vol.2., 1877. (This work is dedicated to du BoisReymond's English friend, Henry Bence-Jones, who almost persuaded du Bois-Reymond to move to London!) The remark that $I$ have quoted is in v. 1 , p. vii.

12 du Bois-Reymond, Emil: Untersuchungen über Thierische Elektricität. Berlin: Reimer, v. 1, 1848; vol. 2, part 1, 1849; vol.2, part 2, 1884 [Bogen 1-24, 1860; Bogen 24-37: 1884].

13 du Bois-Reymond, Emil: Reden. (Edited by Estelle du Bois-Reymond.) Second edition, Leipzig: Veit, vol. 1 and vol.2, 1912.

14 See $n .11$ supra, p. viii, and n. 12 supra, v. 2, part 2, p.501-502.

15 Cranefield, P.F.: The organic physics of 1847 and the biophysics of today. J.Hist. Med. 12: 407-423, 1957; see also Cranefield, P. F.: The philosophical and cultural interests of the biophysics movement of 1847. J. Hist. Med. 21: 1-7, 1966.

16 See $\mathrm{n} .12$ supra, vol. 1 , p. xxxv, and $\mathrm{n} .13$ supra, vol.1, p.9.

17 Frankenstein was originally published anonymously, in London, in 1818. See Mary W. Shelley: Frankenstein or the Modern Prometheus, edited with an introduction by M. K. Joseph. London: Oxford University Press, 1969.

18 See n. 13 supra, vol. 1, p. 1.

19 See n. 3 supra, p. xvi.

20 See n. 3 supra, p.xiv.

\section{Summary}

The personalities and careers of the physiologists Carl Ludwig and Emil du Bois-Reymond are compared and contrasted. Ludwig, who was German, spent an important part of his career in Zürich; du Bois-Reymond, who was Swiss by birth, spent his entire career in Berlin. Ludwig was thoroughly German in every way; du Bois-Reymond, born Swiss, was of Polish and French extraction and was raised in the Frenchspeaking community of Berlin. Ludwig was a master of practical physiological experimentation and of the art of identifying solvable problems and of solving them. Du Bois-Reymond, who was also a skillful inventor of techniques and a skillful experimentalist, nevertheless spent his entire career trying to solve a single problem that could not be solved at that time: the relationship between bio-electric phenomena and the rest of the properties of living systems.

Ludwig and du Bois-Reymond were life-long friend and life-long partners in the effort to explain physiological phenomena in physical and chemical terms, but it was du BoisReymond who was the spokesman for the theoretical position that such phenomena can be explained in that way. Ludwig was a practical man of the laboratory as was du Bois-Reymond, but du Bois-Reymond was much given to discussing sweeping philosophical questions. Although du Bois-Reymond was the arch enemy of vitalism and of the idea of a life force, it is suggested that he may secretly have believed that there is a life force and that it is animal electricity. Both Ludwig and du Bois-Reymond, born just after the Napoleonic wars, in an era very remote from our time, lived through and took part in the scientific and technological changes that shaped the modern era and, in many ways, seem to be men of our time. 


\section{Zusammenfassung}

Der Artikel vergleicht die Persönlichkeiten und die Lebensläufe der Physiologen Carl Ludwig und Emil du Bois-Reymond. Ludwig, ein Deutscher, verbrachte einen wichtigen Teil seiner beruflichen Laufbahn in Zürich; du Bois-Reymond, von Geburt Schweizer, wuchs in Berlin auf und besuchte die dortigen französischen Schulen. Ludwig war ein Meister des physiologischen Experiments und verstand es, Probleme zu erkennen und zu lösen. Auch du BoisReymond war ein geschickter Experimentator, konzentrierte aber seine ganze wissenschaftliche Tätigkeit auf die Lösung eines damals unlösbaren Problems, nämlich des Verhältnisses zwischen den bio-elektrischen Phänomenen und den übrigen Eigenschaften lebender Systeme.

Ludwig und du Bois-Reymond waren zeit ihres Lebens Freunde und Partner in der gemeinsamen Bemühung, physiologische Phänomene physikalisch und chemisch zu erklären. Es war speziell du Bois-Reymond, der postulierte, daß diese Erklärung möglich sein müsse. Beide Forscher waren Praktiker des Laborexperiments, aber speziell du Bois-Reymond vertiefte die Diskussion der philosophischen Aspekte des Problems. Obwohl du Bois-Reymond ein Erzfeind des Vitalismus und des Begriffs der Lebenskraft war, kann vermutet werden, daß er heimlich an die Idee einer Lebenskraft glaubte und daß diese die animalische Elektrizität sei. Beide Forscher wurden kurz nach den napoleonischen Kriegen geboren, also in einer Zeit, die für uns weit zurückliegt. Sie werden aber doch Männer unserer Zeit, denn sie erlebten und förderten die wissenschaftlichen und technischen Umwälzungen, welche die moderne Zeit prägen.

Paul F. Cranefield, M. D., Ph. D.

The Rockefeller University

1230 York Avenue

New York, N. Y. 10021

U.S.A. 